\title{
Isolation, antimicrobial susceptibility patterns, and risk factors assessment of non- typhoidal Salmonella from apparently healthy and diarrheic dogs
}

Belisa Usmael, Bruk Abraha*, Sisay Alemu, Bahar Mummed, Adem Hiko and Abdallahi Abdurehman

\begin{abstract}
Background: Dogs are one of the important asymptomatic carriers of antimicrobial resistant and potentially pathogenic strains of Salmonella. They can harbor large bacterial load in the intestines and mesenteric lymph nodes which can be shed in their feces with the possibility of transmission to humans. Therefore, a cross-sectional study was conducted with the objectives of estimating the prevalence of non-typhoidal Salmonella, assessing the risk factors for dog's Salmonella carriage, and profiling the antimicrobial resistance pattern of Salmonella isolates among housed dogs in Harar town, Eastern Ethiopia. A total of 415 rectal swab samples were collected from randomly selected dogs. Samples were examined for non-typhoidal Salmonella using standard bacteriologic culture and biochemical tests. The disk diffusion method (Kirby-Bauer test) was employed to evaluate the isolates for their susceptibility against five antimicrobials.

Results: Non-typhoidal Salmonella were isolated from 26 (6.3\%) of the rectal swab samples, with significantly higher occurrence in diarrheic (15.2\%) than non-diarrheic (5.5\%) dogs. The risk of Salmonella harboring was significantly higher in female dogs than in male dogs $(\mathrm{OR}=2.5, p=0.027)$. Dogs fecal shedding of Salmonella was relatively higher in households who used offal as a main feed type for their dogs $(23.1 \% ; 95 \% \mathrm{Cl}=5-53.8)$ than those who used leftover food (10.1\%; 95\% Cl=5.7-16.1) and practiced mixed feeding system (17\%; $95 \% \mathrm{Cl}=7.6-30.8)$. Salmonella isolates showed higher resistance to ampicillin (41.7\%), while all isolates were fully susceptible to gentamicin. Moreover, $58.3 \%$ of Salmonella isolates showed resistance to at least one of the tested antimicrobials. Majorities (72.7\%) of the dog owners had no awareness on the risk of zoonotic salmonellosis from dog and all of the respondents use bare hand to clean dog kennel.

Conclusion: Our study reveals the importance of both diarrheic and apparently healthy housed dogs in the harboring and shedding of antimicrobial resistant non-typhoidal Salmonella. The risk of non-typhoidal Salmonella spread among pet owners is not negligible, especially in households who use offal as main feed type. Therefore, an integrated approach such as: proper dog handling practices; continuous evaluation of antimicrobial resistance; and rational use of antimicrobials in the field of veterinary sector are necessary to tackle the problem.
\end{abstract}

Keywords: Antimicrobial resistance, Dog, Non-typhoidal Salmonella, Prevalence, Risk factors

\footnotetext{
*Correspondence: abraha.ashebr@yahoo.com; Bruk.Abraha@haramaya.edu.

et

College of Veterinary Medicine, Haramaya University, P.O. Box 138, Dire

Dawa, Ethiopia
}

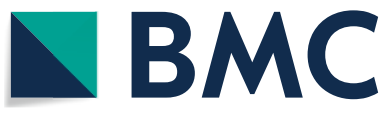

(c) The Author(s) 2022. Open Access This article is licensed under a Creative Commons Attribution 4.0 International License, which permits use, sharing, adaptation, distribution and reproduction in any medium or format, as long as you give appropriate credit to the original author(s) and the source, provide a link to the Creative Commons licence, and indicate if changes were made. The images or other third party material in this article are included in the article's Creative Commons licence, unless indicated otherwise in a credit line to the material. If material is not included in the article's Creative Commons licence and your intended use is not permitted by statutory regulation or exceeds the permitted use, you will need to obtain permission directly from the copyright holder. To view a copy of this licence, visit http://creativecommons.org/licenses/by/4.0/. The Creative Commons Public Domain Dedication waiver (http://creativeco mmons.org/publicdomain/zero/1.0/) applies to the data made available in this article, unless otherwise stated in a credit line to the data. 


\section{Introduction}

Salmonella is the causative agent of both human and animal salmonellosis. The bacterium causes infections ranging from subclinical carrier state to acute fatal septicemia [1]. It is a potential cause of acute and chronic diarrhea and death in numerous animal species and in human beings [2]. Particularly, salmonellosis in animals is a major concern, because animals can shed Salmonella serotypes into the environment without any apparent clinical signs [3]. Salmonella is widespread in the environment and commonly found in farm effluents, human sewage and in any material subjected to fecal contamination [4]. Due to considerable geographical and temporal variation in the prevalence of Salmonella species in animals and humans, understanding the role of animals in zoonotic transmission is important to monitor salmonellosis [5].

Non-typhoidal Salmonella is an important zoonosis worldwide. It is reported that globally an estimated 65-380 million illnesses and 43-88 thousand deaths of human beings were associated with non-typhoidal S. enterica from the year 1990 to 2012 [6]. As of 2002, zoonotic Salmonella strains such as S. typhimurium, S. Heidelberg, and S. enteritidis accounts for 17, 11, and 9\% of Salmonella sourced from non-human subjects [7]. One of the sources for human salmonellosis is feces of pet dogs [8] and there have been reports on transmission of Salmonella from dogs to humans $[9,10]$. It was reported that dogs can harbor large bacterial load $\left(10^{2}-10^{6}\right.$ per $100 \mathrm{~g}$ of feces $)$ in their intestine, which can be shed in their feces for several months [11]. Thus, this carriage could be of significant importance to public health as dogs have close contact with family members in households [12].

Different scholars reported antimicrobial resistant Salmonella isolates from food samples [13], animals [14, 15] and human $[16,17]$ in Ethiopia. Due to the emergence and spread of antimicrobial-resistant strains, there is an increasing concern with this pathogen [18]. The concern of antimicrobial resistance is particularly important in developing countries, because of inadequate adherence to prudent use of antimicrobials; unhygienic living conditions; and close contact and sharing of houses between animals and humans [19].

Some reports have shown the occurrence of Salmonella in dogs from different parts of the globe. For instance, United States [20, 21], the United Kingdom [22], Thailand [23], Taiwan [24], Turkey [25, 26], and Trinidad [27]. It has been well known for several decades that dogs may carry Salmonella species in their intestinal tracts, mainly as an asymptomatic carrier state $[9,28]$. Gastrointestinal disease manifested as enterocolitis and endotoxemia can occur and is often associated with fever, vomiting, anorexia, dehydration, and depression [29, 30]. Pet feed preparations play crucial role in the transmission of Salmonella among housed dogs, because raw meat-based dogs feed tends to contain significantly higher Salmonella spp. than commercial dry feed [31]. Furthermore, it was reported that Salmonella was found in $21 \%$ commercial raw food diets, representing combinations of raw meat, vegetables, grain, and eggs or fruit [32]. Contamination rates in dry or canned foods are thought to be considerably lower, and Salmonella has not been isolated from canned dog food [33].

Studies in Ethiopia showed that majority of livestock owners have the habit of using antimicrobials to treat animal diseases [34, 35]. However, the antimicrobial usage is characterized by shortcomings such as: inability to define the specific purposes of prescribed drug and lack of awareness on the risks of antimicrobial resistance [34]; the use of human preparation for veterinary purposes, inappropriate dosages, incomplete treatment regimens, lack awareness on the recommended withdrawal periods [35]; and limited access to antimicrobial varieties [34, 35]. In Ethiopia, pet dogs are integral part of the society, which is evidenced by household's dog ownership ranging from 33 to $40.5 \%$ in towns $[36,37]$ and $75.5 \%$ in rural communities [37]. Despite the increasing urbanization in major towns of Ethiopia, only few studies have shown the status of Salmonella in housed dogs [15, 38, 39]. Moreover, these studies failed to provide detailed information on the risk factors for dog salmonellosis and there is limited information on the antimicrobial susceptibility profiles of clinical isolates. Therefore, the objectives of this study were to estimate the prevalence of non-typhoidal Salmonella isolates, to assess the risk factors associated with Salmonella occurrence, and to identify antimicrobial susceptibility profiles of the isolates from apparently healthy and diarrheic dogs in Harar town, Eastern Ethiopia.

\section{Results \\ Overall prevalence of Salmonella in dogs}

From 415 dogs examined, 26 (6.3\%) were positive for Salmonella. The present study showed that the point estimates for prevalence of Salmonella in apparently healthy and diarrheic dogs was 5.5 and $15.2 \%$ respectively. Confidence intervals are given in Table 1.

\section{Prevalence of Salmonella in dogs and households among Kebeles}

The prevalence varied among kebeles, in that it was higher in kebele 10 (10\%) followed by kebeles 15 (9.9\%), 16 (7.0\%), 18 (3.4\%), 13 (1.6\%), and 17 (0\%) (Table 2) but with no significant variation among the kebeles. Among the 209 households, Salmonella was detected in 12.4\% 
Table 1 Prevalence of Salmonella based on clinical status of sampled dogs in Harar town

\begin{tabular}{llll}
\hline Clinical state & Number of dogs examined & Number positive for Salmonella & Prevalence in \% (95\% Cl) \\
\hline Apparently healthy & 382 & 21 & $5.5(3.4-8.3)$ \\
Diarrheic & 33 & 5 & $15.2(5.1-31.9)$ \\
Total & 415 & 26 & $6.3(4.1-9.0)$ \\
\hline
\end{tabular}

Table 2 Prevalence of Salmonella across the studied kebeles of Harar town, eastern Ethiopia

\begin{tabular}{lllll}
\hline Kebeles & $\begin{array}{l}\text { Total } \mathbf{N} \text {. of dogs } \\
\text { examined }\end{array}$ & $\begin{array}{l}\text { Number of dogs positive for } \\
\text { Salmonella (\%) }\end{array}$ & $\begin{array}{l}\text { Total household } \\
\text { examined }\end{array}$ & $\begin{array}{l}\text { Number of household } \\
\text { positive For Salmonella } \\
(\%)\end{array}$ \\
\hline 15 & 101 & $10(9.9)$ & 72 & $10(13.9)$ \\
16 & 142 & $10(7.0)$ & 66 & $10(14.9)$ \\
13 & 61 & $1(1.6)$ & 23 & $1(4.3)$ \\
10 & 30 & $3(10)$ & 12 & $3(25)$ \\
18 & 59 & $2(3.4)$ & 29 & $2(6.9)$ \\
17 & 22 & $0(0)$ & 7 & $20(0)$ \\
Total & 415 & $26(6.3)$ & & 209 \\
\hline
\end{tabular}

with varied frequencies among the kebeles (Table 2). However, kebele had no significant association with the occurrence of Salmonella both at animal and household levels. Except in kebele 17, Salmonella positive dogs were found among households in all kebeles and the prevalence varied numerically with the highest being in kebele 10 (25\%) (Table 2).

\section{Risk factors for Salmonella in dogs}

As shown in Table 3, Salmonella prevalence was significantly higher in female (10.1\%) than males (4.3\%) and in diarrheic dogs $(15.2 \%)$ than apparently healthy (5.5\%). Female dogs had 2.5 times the odd of shedding Salmonella in their feces than male dogs $(P<0.05)$. The odds of Salmonella shedding in thin and fat body conditioned dogs were 2.8 and 1.5 times, respectively higher than medium body conditioned once. Meanwhile, dogs fed uncooked preparations had 2.0 times the odds of harboring Salmonella than those fed with cooked preparations. However, there was no significant difference with respect to breed, age, feeding, feed treatment, BCS, and educational status of dog owners (Table 3).

In this study, a relatively higher prevalence of Salmonella shedding was observed in households who used offal as main feed type for their dogs (23.1\%) than those who used leftover food (10.1\%) and practiced mixed feeding system (17\%) (Table 4).

\section{Antimicrobial susceptibility profiles of Salmonella isolates} All $(n=24)$ the tested isolates were susceptible to gentamicin, while varied proportions of resistance were observed against the other tested antimicrobials. Thus, relatively high resistance was observed against ampicillin $(41.7 \%)$ followed by tetracycline $(21.2 \%)$, amoxicillinclavulanate (12.5\%), and trimethoprim-sulfamethoxazole (4.2\%) (Fig. 1). The control organism was susceptible to all tested antimicrobials.

The study showed that $58.3 \%$ of Salmonella isolates were resistant to at least one of the tested antimicrobials (Table 5). The dominant isolates were those showed resistance against ampicillin only at a proportion of 20.8\%. Meanwhile, from the total Salmonella isolates examined, $2(8.3 \%)$ had shown resistance to two antimicrobial classes, with a resistance pattern to ampicillin, tetracycline, and amoxicillin-clavulanate. Moreover, the study revealed that resistant isolates showed similar distribution across the candidate risk factors for dog salmonellosis (Table 6).

\section{Dog handling practices in relation to Salmonella control}

Practices related to dog handling, feeding, and hygiene had varied among households (Table 7). Thus, it was observed that majority (71.3\%) of dog owners used leftover food as dog feed and none of them used commercial diet for the feeding of dog. Regarding feed treatment, majority (90.9\%) of the households used occasional cooking of feed. Moreover, it was recorded that majority $(72.7 \%)$ of the dog owners had no awareness on the risk of zoonotic dog salmonellosis. In addition, all of the owners responded that they used to clean dog's kennel with bare hands. 
Table 3 Results of analysis on potential risk factors for Salmonella shedding by dogs in Harar town, Eastern Ethiopia

\begin{tabular}{|c|c|c|c|c|c|}
\hline \multirow[t]{2}{*}{ Variables } & \multirow{2}{*}{$\begin{array}{l}\text { №. of Animals } \\
\text { examined }\end{array}$} & \multirow{2}{*}{$\begin{array}{l}\text { №. of Animals with } \\
\text { Salmonella (\%) }\end{array}$} & \multirow[t]{2}{*}{$x^{2}$ value ( $p$-value) } & \multicolumn{2}{|c|}{ Univariable LG analysis } \\
\hline & & & & Odds ratio $(95 \% \mathrm{Cl})$ & $p$-value \\
\hline \multicolumn{6}{|l|}{ Sex } \\
\hline Female & 139 & $14(10.1)$ & $5.158(0.023)$ & $2.5(1.1-5.5)$ & 0.027 \\
\hline Male & 276 & $12(4.3)$ & & * & \\
\hline \multicolumn{6}{|l|}{ Breed } \\
\hline Local & 306 & $20(6.5)$ & $0.146(0.732)$ & $1.2(0.5-3.1)$ & 0.703 \\
\hline Cross & 109 & $6(5.5)$ & & $*$ & \\
\hline \multicolumn{6}{|l|}{ Age } \\
\hline Young & 189 & $11(5.8)$ & $0.117(0.732)$ & * & \\
\hline Old & 226 & $15(6.6)$ & & $1.2(0.5-2.6)$ & 0.732 \\
\hline \multicolumn{6}{|l|}{ BSC } \\
\hline Medium & 284 & $14(4.9)$ & $3.600(0.135)$ & $*$ & \\
\hline Fat & 97 & $8(8.2)$ & & $1.5(0.4-5.3)$ & 0.543 \\
\hline Thin & 34 & $4(11.8)$ & & $2.8(0.8-8.3)$ & 0.115 \\
\hline \multicolumn{6}{|l|}{ Feeding } \\
\hline Leftover & 288 & $15(5.2)$ & $2.596(0.262)$ & $*$ & \\
\hline Offal's & 27 & $3(11.1)$ & & $1.6(0.6-4)$ & 0.312 \\
\hline Both & 100 & $8(8)$ & & $1.4(0.4-5.8)$ & 0.612 \\
\hline \multicolumn{6}{|l|}{ Feed Rx } \\
\hline Uncooked & 31 & $1(3.2)$ & $0.527(0.404)$ & $2.0(0.3-1.6)$ & 0.478 \\
\hline Mixed & 384 & $25(6.5)$ & & $*$ & \\
\hline \multicolumn{6}{|l|}{ Diarrheic } \\
\hline No & 382 & $21(5.5)$ & $4.821(0.045)$ & - & - \\
\hline Yes & 33 & $5(15.2)$ & & - & - \\
\hline \multicolumn{6}{|l|}{ Educational status: } \\
\hline Below high school & 251 & $17(6.8)$ & $0.279(0.597)$ & $1.3(0.5-2.9)$ & 0.598 \\
\hline High school and above & 164 & $9(5.5)$ & & $*$ & \\
\hline
\end{tabular}

No. Number, LG Logistic regression, CI Confidence Interval, BCS Body condition score, $R x$ Treatment

${ }^{*}$ Explanatory variables

Table 4 Owners' awareness on the risk of zoonotic transmission of dog Salmonella among households of Harar town, Eastern Ethiopia $(n=209)$

\begin{tabular}{|c|c|c|c|c|c|}
\hline Variable items & Category & $\begin{array}{l}\text { No. of } \mathrm{HH} \\
\text { respondents }\end{array}$ & No. positive & Prevalence in \% $(95 \% \mathrm{Cl})$ & Chi-square ( $p$ value) \\
\hline \multirow[t]{3}{*}{ Feed type } & Leftover food & 149 & 15 & $10.1(5.7-16.1)$ & $3.026(0.220)$ \\
\hline & Offal & 13 & 3 & $23.1(5-53.8)$ & \\
\hline & Mixed & 47 & 8 & $17(7.6-30.8)$ & \\
\hline \multirow[t]{2}{*}{ Feed treatment } & Uncooked & 19 & 1 & $5.3(0.1-26.0)$ & $0.988(0.320)$ \\
\hline & Mixed & 190 & 25 & $13.2(8.7-18.8)$ & \\
\hline \multirow[t]{2}{*}{ Educational status of dog owners } & Below high school & 119 & 17 & $14.3(8.5-21.9)$ & $0.864(0.238)$ \\
\hline & High school and above & 90 & 9 & $10(4.7-18.1)$ & \\
\hline \multirow{2}{*}{$\begin{array}{l}\text { Knowledge on transmission of } \\
\text { Salmonella to human }\end{array}$} & Yes & 57 & 10 & $17.5(6.1-16.5)$ & $1.874(0.171)$ \\
\hline & No & 152 & 16 & $10.5(8.7-29.9)$ & \\
\hline
\end{tabular}

$n$ Number of households examined, No. Number, $\mathrm{HH}$ Households 


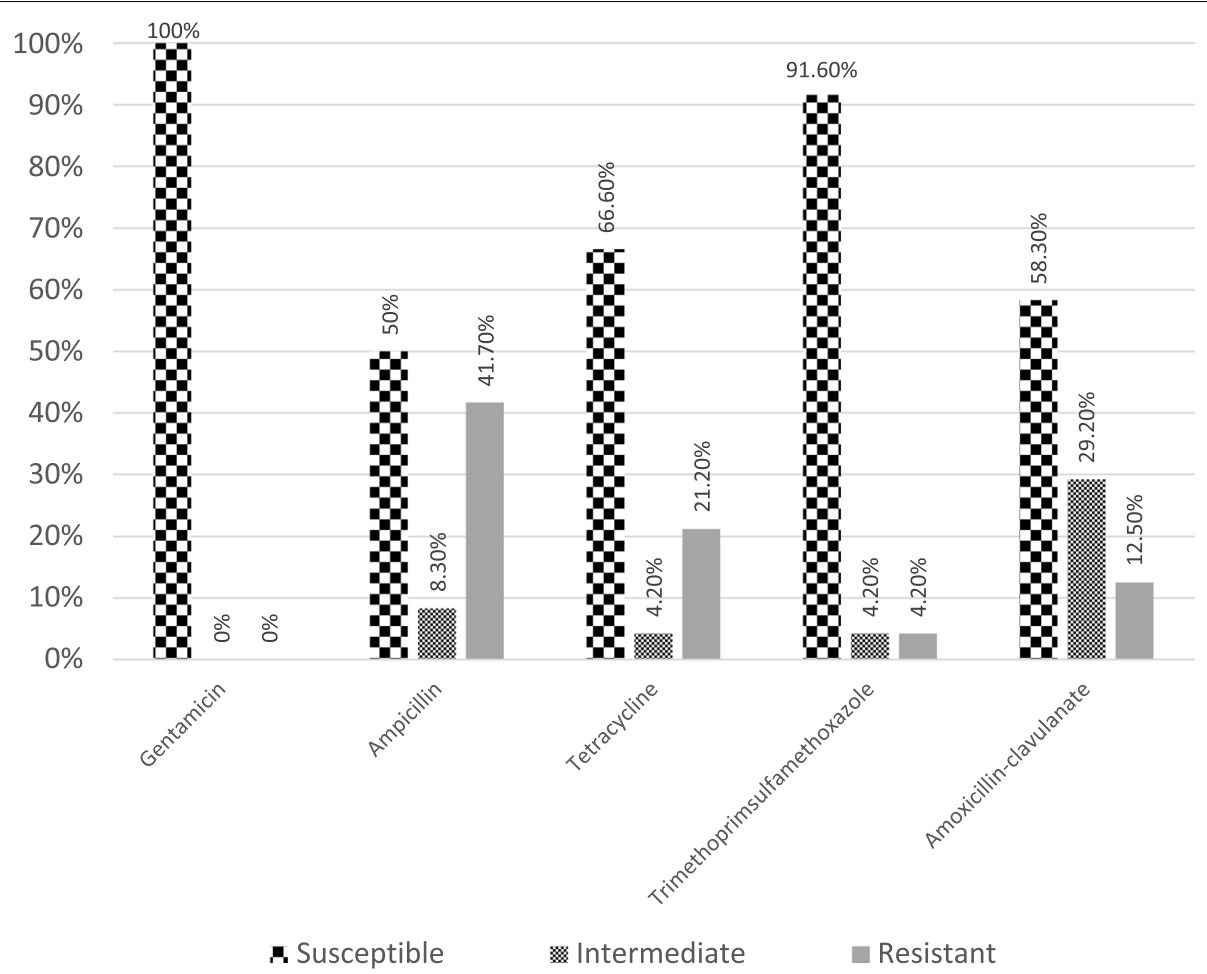

Fig. 1 In-vitro antimicrobial susceptibility of the isolated Salmonella $(n=24)$

Table 5 Drug resistance patterns of Salmonella isolates $(n=24)$

\begin{tabular}{llll}
\hline Resistant to: & $\begin{array}{l}\text { Name of the } \\
\text { antimicrobial }\end{array}$ & \multicolumn{2}{l}{ Resistant isolates } \\
\cline { 3 - 4 } & & Number & $\%$ \\
\hline None & - & 10 & 41.7 \\
One drug & AMP & 5 & 20.8 \\
\multirow{2}{*}{ Two drugs } & TTC & 4 & 16.6 \\
& AMP,TMS & 1 & 4.2 \\
Three drugs & AMP, AMC & 1 & 4.2 \\
Overall & AMP, TTC & 1 & 4.2 \\
\hline
\end{tabular}

Key: $n$ Number, AMP Ampicillin, TTC Tetracycline, TMS Trimethoprimsulfamethoxazole, AMC Amoxicillin-clavulanate

\section{Discussion}

Our study has focused on prevalence study for Salmonella carriage in apparently healthy and diarrheic dogs based on bacteriologic culture and biochemical identification. In addition, an invitro antimicrobial test was conducted using disc diffusion method to observe the resistance profiles of Salmonella isolates against five antimicrobials used in the veterinary as well as human medicine. The study also attempts to elucidate the potential risks for the transmission of salmonellosis in dogs as well as humans using a prepared questionnaire format.

Our study showed that the fecal shedding of Salmonella among pet dogs located in Harar town of eastern Ethiopia was $6.3 \%$, in which significantly higher prevalence was recorded in diarrheic dogs (15.2\%) as compared to the apparently healthy once (5.5\%). This finding is within the range of 0 to $44 \%$ subclinical carriage of Salmonella in dogs [40]. This higher prevalence of Salmonella in diarrheic dogs is supported by previous findings in different parts of the globe [8, 41-43]. However, authors like Sultan et al. [38] and Zewdu et al. [39] reported that the prevalence did not vary significantly between clinically healthy and diarrheic dogs in Ethiopia.

The sub-clinical shedding of Salmonella by housed dogs has been reported from different countries, but the prevalence varies. For instance, overall sub-clinical Salmonella shedding in our study (5.5\%) is in line with the report of Amadi et al. [44] and Leahy et al. [20] from Grenada (5.6\%) and USA (4.9\%), respectively. In contrary to our finding, studies showed lower sub-clinical carriage, such as: $0 \%$ [45]; $2.3 \%$ [46]; $1 \%$ [26]; $1.2 \%$ [47]; and $0.2 \%$ [48] from New Zealand, USA, Turkey, Canada, and United Kingdom, respectively. This indicates the fact that owners in developed countries may be more focused on the importance of hygiene and make use of the available 
Table 6 Antimicrobial susceptibility profiles of Salmonella isolates based on risk categories

\begin{tabular}{llll}
\hline Categories & Number (\%) of isolates: & & Susceptible to all \\
\cline { 2 - 4 } & Resistant to TTC & Resistant to AMP & \\
\hline $\begin{array}{l}\text { Age } \\
\quad \text { Young }(n=10)\end{array}$ & $3(30)$ & $4(40)$ & $5(50)$ \\
$\quad$ Old $(n=14)$ & $4(28.6)$ & $6(42.9)$ & $5(35.7)$ \\
Feed & & & $6(46.2)$ \\
$\quad$ Leftover food $(n=13)$ & $2(15.9)$ & $4(30.8)$ & $4(36.4)$ \\
Offal based $(n=11)$ & $5(45.5)$ & $6(54.5)$ & $3(27.3)$ \\
Sex & $3(27.3)$ & $6(54.5)$ & $7(53.8)$ \\
$\quad$ Male $(n=11)$ & $4(30.8)$ & $4(30.8)$ & $3(60)$ \\
$\quad$ Female $(n=13)$ & & & $7(36.8)$ \\
Breed & $2(40)$ & $2(40)$ & $8(42.1)$ \\
$\quad$ Cross $(n=5)$ & $5(26.3)$ & & \\
Local $(n=19)$ & & & \\
\hline
\end{tabular}

$n$ Number of Salmonella isolates tested from each variable category, AMP Ampicillin, TTC Tetracycline

Table 7 Summary of dog management practices and dog owner's awareness on the risk of zoonotic transmission of Salmonella $(n=209)$

\begin{tabular}{llll}
\hline Variable items & Response & $\begin{array}{l}\text { Number of } \\
\text { respondents }\end{array}$ & $\%$ \\
\hline Feed types & Commercial diet & 0 & 0 \\
& Leftover food & 149 & 71.3 \\
& Offal & 11 & 5.3 \\
& Mixed & 49 & 23.4 \\
Feed treatment & Uncooked & 19 & 9.1 \\
& Always cooked & 0 & 0 \\
House cleaning & Sometimes cooked & 190 & 90.9 \\
& Use glove & 0 & 0 \\
Water source & Bare hand & 209 & 100 \\
Addition of drug to feed & No clean & 0 & 0 \\
& Tap water & 209 & 100 \\
Knowledge on transmis- & Ground water & 0 & 0 \\
sion of Salmonella to & Yes & 0 & 0 \\
human & No & 209 & 100 \\
\hline
\end{tabular}

$n$ Number of households examined

veterinary care for their animals [49]. On the other hand, different authors have reported higher prevalence such as: $20.8 \%$ [50]; $10.5 \%$ [3]; $43.7 \%$ [51]; $13.2 \%$ [43]; $11.7 \%$ [15]; and $17.1 \%$ [38] from USA, Iran, Northeastern Nigeria, Thailand, Addis Ababa, and Holeta town of Ethiopia, respectively. Generally, prevalence is influenced by factors such as pet sanitary practices, feeding habit, difference in public awareness about dog zoonosis, and socioeconomic status of the owners. Despite the above facts, season of study, geographical areas, and diagnostic methods employed might have also accounted for the observed difference as described by Seepersadsingh et al. [27].

In our findings, there was no significance difference between feeding of leftover, offal and both (leftover and offal). But the prevalence is higher in dogs fed on offal (11.1\%) as compared to dogs fed on household leftover food (5.2\%) and mixed diet (8\%). In agreement with the present finding, Finley et al. [52] reported higher fecal shedding of Salmonella in dogs fed on raw meat and offal diets. Schotte et al. [53] stated that feeding raw meat and other uncooked diets were risk factors for carriage of Salmonella in dogs. PHAC (Public Health Agency of Canada) [54] reported that raw meat and meat products were frequently contaminated with Salmonella, and consequently, homemade raw diets were considered as a potential source of Salmonella. Freeman et al. [55] observed that the known infection risk to owners is highly relevant when pets are consuming Salmonella contaminated feed. Reports from Ethiopia showed that $8.5-13.5 \%$ of examined chicken, pork, mutton, and beef harbor different serotypes of Salmonella [13, 56]. Other reports indicate that Salmonella is prevalent in animals, humans, and food items in different parts of Ethiopia, suggesting that Salmonella can be prevalent in dogs $[57,58]$.

Our study shows that Salmonella shedding was significantly higher in female than male dogs. However, Jajere et al. [59] from Nigerian reported that male dogs had significantly higher Salmonella infection than females. In contrary, previous studies from Taiwan [24], Ontario [42], and Mexico [60] showed insignificant difference 
among male and female dogs. Similarly, from Ethiopia various authors indicated that the prevalence didn't vary significantly among sex categories of studied dogs [15, 38, 39]. These disparities might not in fact reflect a real phenomenon, but just statistical variation resulting from confounding factors/variables.

In our findings, there was no significance difference between medium, fat and thin body condition score of the dogs, which is in accordance with the reports of Kiflu et al. [15], Sultan et al. [38], and Zewdu et al. [39], in that insignificant difference in the prevalence of Salmonella was recorded between body condition categories of studied dogs. Similarly, our study didn't show significance difference between age categories of dogs. Furthermore, Sultan et al. [38] and Kiflu et al. [15] reported insignificant difference in the prevalence of Salmonella between age groups examined. In contrary to our finding, Núñez-Castro et al. [61] from Mexico reported that dogs under 1 year are more likely to acquire Salmonella than dogs older than 1 year, while Zewdu et al. [39] from Ethiopia reported that older dogs harbor more Salmonella than younger dogs. Often it is difficult to compare different findings, because different age profiles are seen in different studies and it is confounded by differences in sampled population lifestyles and owners dog caring practices. Literatures generally mentioned that younger animals are more susceptible to most of bacterial infections, mainly due to the immature immune system. However, both young and adult animal can be asymptomatic carriers of Salmonella [1, 11, 62].

Our finding shows that all Salmonella isolates were susceptible to gentamicin. However, previous antimicrobial resistance studies on dog isolates of Salmonella species reported resistance to gentamicin in Taiwan (5\%) [24] and Nigeria (35.3\%) [8]. This may reflect the fact that gentamicin is not commonly used in veterinary sector in Ethiopia, particularly Harar town (Source: researcher's personal observations and clinical experiences). Meanwhile, some isolates have shown resistance against ampicillin (41.7\%), tetracycline (21.2\%), amoxicillin-clavulanate $(12.5 \%)$, and trimethoprim-sulfamethoxazole (4.2\%). This high proportion of resistance against ampicillin and tetracycline might reflect their frequent use in veterinary medications. From Ethiopia, Beyene et al. [63] suggest that high-rate of resistance to oxytetracycline is due to the fact that this drug is the most commonly used antimicrobial agent in animal medications. Similarly, a previous study in Taiwan showed resistant isolates to tetracycline $(77.5 \%)$ and sulfamethoxazole/trimethoprim (37.5\%) [24]. From Nigeria, it was reported that Salmonella isolates showed resistance to tetracycline (70.6\%), ampicillin (47.1\%), and amoxicillin-clavulanic acid $(87.6 \%)[8,51]$. A previous report from Ethiopia indicates that 30.9 and $59.5 \%$ of Salmonella isolates from dogs showed resistance to ampicillin and tetracycline, respectively [15]. These findings indicate that Salmonella drug resistance can vary from country to country and even from one area to another area in the same country. The feeding habits of dogs play an important role in contracting drug resistant strains. For instance, Kiflu et al. [15] from Addis Ababa reported that majority of dog owners in the city used raw animal products to feed their dogs. In relation to this, Bedada and Molla [64] showed that $71.3 \%$ of beef obtained from cattle slaughtered in central Ethiopia contained oxytetracycline residues.

Majority of the Salmonella isolates (58.3\%) were resistant to at least one of the tested antimicrobials. Moreover, $8.3 \%$ of the isolates showed resistance against three drug types (i.e., ampicillin, tetracycline, and amoxicillinclavulanate). This shows that apparently healthy dogs could harbor drug resistant Salmonella thereby serving as a source of human infection. A better understanding of the interplay of factors that contribute to the dissemination and establishment of multidrug resistant isolates is necessary.

\section{Conclusion}

Our study revealed that non-typhoidal Salmonella occurred at higher frequency in diarrheic than apparently healthy dogs with an occurrence in almost all studied small administration units (kebeles). Salmonella occurrence was relatively higher in dogs managed at households who used offal as main feed type for their dogs than those who used leftover food and practiced mixed feeding system. Thus, dogs might play a significant role in spreading of the organism to humans as well as other animals. Moreover, the high carriage rate of Salmonella isolates resistant to varied antimicrobials used in the medications of humans and animals signals an important threat in both the veterinary and public health sectors as it limits antimicrobial drugs available for the effective control of Salmonella infections. Regular investigations on the circulating serotype as well as assessing the multi-drug resistance profiles may assist in controlling the occurrence of zoonotic salmonellosis in areas where large proportion of households use dogs as a pet animal.

\section{Materials and methods Study area}

The study was conducted in Harar town, which is located around $9^{\circ} \mathrm{N}$ latitude and $42^{\circ} \mathrm{E}$ longitude and at a distance of about $526 \mathrm{~km}$ East of Addis Ababa, the capital of Ethiopia. Harar town has mean annual temperature of $28^{\circ} \mathrm{C}$ [65]. The altitude of the town is $1850 \mathrm{~m}$ above sea level and its mean annual rainfall and humidity measures $596 \mathrm{~mm}$ and $60.3 \%$, respectively [66]. The total human 
population of the town was estimated at 125,000 with annual growth rate of $2.6 \%$ as of the year 2014 [67].

\section{Study population and sampling units}

The study population was dogs owned by residents of Harar town. Among the 19 kebeles (i.e. the smallest administrative units of the town) in Harar town, six were randomly selected. Apparently healthy and diarrheic dogs regardless of age, sex, breed, and dog care practices were included in the study. All dogs included were those who didn't took any medication with antimicrobial activity for the past 4 weeks prior to sampling.

\section{Study design}

A cross-sectional study was conducted from January 2020 to August 2020 to estimate the prevalence of Salmonella from rectal swab sample of dogs in selected kebeles of Harar towns, Harari Regional State, eastern Ethiopia. Dogs were sampled through door-to-door visit from households. Invitro-experimental study was employed to identify the antimicrobial susceptibility patterns of Salmonella isolates.

\section{Sample size determination}

The sample size was determined using the formula given by Thrusfield [68] by assuming simple random sampling. As there was no previous study on dog salmonellosis, the sample size was determined by assuming $50 \%$ expected prevalence; $5 \%$ desired absolute precision at $95 \%$ confidence interval; and based on the assumption of large dog population existing in the town. Thus, with two missed samples, 382 dogs were sampled. In addition, 33 dogs with signs of salmonellosis (diarrhea and septicemia) encountered during the study period were purposively included in the study. Diarrheic dog was defined as an animal presented by owner with a current problem of diarrhea [68].

$$
\mathrm{n}=\frac{1.96^{2} X \operatorname{Pexp}(1-\operatorname{Pexp})}{\mathrm{d}^{2}}
$$

Where $\mathrm{n}=$ sample size.

$\mathrm{P}_{\text {exp }}=$ expected prevalence.

$\mathrm{d}=$ desired absolute precision.

\section{Sample and data collection}

Prior to sample collection, individual animal's history of medication with antimicrobial agents was noted. Then rectal swab sample was collected from each dog after proper restraining with the help of the owner. The samples were placed into a sterile buffered peptone water (HiMedia, India) and transported to Haramaya University Veterinary Microbiology Laboratory in box containing ice packs. Samples were processed for bacterial culture within $12 \mathrm{~h}$ of arrival. In addition, questionnaire and observational survey were used to gather data on feeding practices (cooked animal products and mixed [raw meat, cooked animal products and household leftover]) and sampled animal attributes such as sex, breed, body condition, and age.

\section{Isolation and identification of Salmonella}

Isolation and identification of Salmonella from rectal swab samples were performed according to the procedure recommended by the international standard organization (ISO) for isolation of Salmonella [69]. Rectal swab samples were transferred into a tube with $9 \mathrm{ml}$ of buffered peptone water (HiMedia, India), shaken for approximately $2 \mathrm{~min}$ and incubated at $37 \pm 1{ }^{\circ} \mathrm{C}$ for $18 \pm 2 \mathrm{~h}$. A portion of the culture $(0.1 \mathrm{ml})$ was transferred into a tube containing $10 \mathrm{ml}$ of selective enrichment liquid media (Rappaport-Vassiliadis, HiMedia, India) and incubated at $42^{\circ} \mathrm{C}$ for $24 \pm 3 \mathrm{~h}$. Similarly, $1 \mathrm{ml}$ of the culture was transferred to a tube containing $10 \mathrm{ml}$ of tetrathionate broth (Conda S.A., Spain) and incubated at $37^{\circ} \mathrm{C}$ for $24 \pm 3 \mathrm{~h}$. A loopful of inoculum from each of enrichment cultures was then inoculated on the surface of two different plates, xylose lysine deoxycholate (XLD) agar (Sisco research lab, India) and brilliant green agar (BGA) (HiMedia, India) and then incubated at $37^{\circ} \mathrm{C}$ for $24 \pm 3 \mathrm{~h}$. For confirmation, presumptive Salmonella colonies from both XLD and BGA agar were selected and streaked onto the surface of pre-dried nutrient agar (Oxoid, England) plates and incubated at $37^{\circ} \mathrm{C}$ for $24 \pm 3 \mathrm{~h}$. Colonies from nutrient agar were tested for catalase, oxidase, and Gram's reaction. Presumptive isolates were inoculated into the following biochemical test tubes for identification: triple sugar iron (TSI) agar (HiMedia, India), Simmon "s citrate agar (HiMedia, India), Sulphide Indole Motility (SIM) medium (Sisco research lab, India) and incubated for 24 or $48 \mathrm{~h}$ at $37^{\circ} \mathrm{C}$. Colonies producing an alkaline (red) slant with acid (yellow) butt with hydrogen sulphide production (blackening) on TSI, positive for citrate utilization (blue color), and negative for tryptophan utilization (Indole test) (yellow-brown ring), and negative for urea utilization were considered as Salmonella [70]. In addition, all of the tested isolates were motile. Positive control isolate/strain was obtained from Ethiopian Public Health Institute (EPHI), Addis Ababa, Ethiopia.

\section{Antimicrobial susceptibility test of Salmonella isolates}

Susceptibility of the isolates to five antimicrobials was determined using the disk diffusion method according to the guidelines of Clinical and Laboratory Standards Institute [71]. Briefly, frozen isolates were sub-cultured on tryptic soy agar (Becton, Dickinson and Company, USA) 
from which 3 to 4 pure colonies were further inoculated in to a tube containing $5 \mathrm{ml}$ of tryptic soy broth (TSB) (Becton, Dickinson and Company, USA). The tubes were then incubated at $37^{\circ} \mathrm{C}$ for $4-5 \mathrm{~h}$. The turbidity of each suspension was then adjusted to 0.5 McFarland turbidity standard using sterile saline solution. Sterile cotton swab was dipped and rotated several times and pressed firmly on the inside wall of the tube above the fluid level to remove excess inoculum. It was then spreading on to the entire surface of Mueller-Hinton agar plate (Oxoid, Ltd). The inoculated plates were left at room temperature to for $5-10 \mathrm{~min}$ until excess moisture is removed and antimicrobial discs were placed by pressing on the plate with sterile forceps. The plates were then inverted and incubated overnight at $35^{\circ} \mathrm{C}$. Diameters of the zone of inhibition were measured to the nearest millimeter using a plastic transparent ruler. The interpretation of the categories of susceptible, intermediate or resistant was based on the CLSI guidelines [71]. For the purpose of analysis, all readings classified as intermediate were considered as resistant unless indicated. Reference strain of Salmonella Typhi ATCC 27853 was used as a quality control. The antimicrobial discs (Sensi-Discs, Becton, Dickinson and Company, Loveton, USA) were amoxicillin + clavulanic acid $(20 / 10 \mu \mathrm{g})$, gentamicin $(10 \mu \mathrm{g})$, tetracycline $(30 \mu \mathrm{g})$, sulfamethoxazole and trimethoprim $(23.75$ and $1.25 \mu \mathrm{g})$, and ampicillin $(10 \mu \mathrm{g})$.

\section{Data management and analysis}

All collected data were entered and coded using Microsoft Excel Spreadsheet. Statistical analysis was made using STATA software version 11.0 (STATACORP, 2009). Before analysis, the age of dog was classified in to two group young (less than 2 years) and old ( $\geq 2$ years). in addition, body condition score was done based on 5 scale (emaciated, thin, ideal (medium), fat, and obese) according to AAHA (American Animal Hospital Association). Descriptive statistics such as frequency and percentage were used to describe the practices, knowledge and awareness in the community regarding the disease. Chisquare, Fisher exact test and logistic regression analyses were used to assess the association of risk factors with the prevalence of Salmonella. In all the cases, $P<0.05$ was considered as significant association.

\section{Abbreviations}

BGA: Brilliant Green Agar; TSI: Triple Sugar Iron; XLD: Xylose Lysine Deoxycholate.

\section{Acknowledgements}

The authors are thankful to Haramaya University for facilitating the work and availing the laboratory reagents, consumables, and facilities. Particularly, we are thankful to staff members in veterinary microbiology laboratory of Haramaya University for their support during the laboratory work.

\section{Authors' contributions}

B.U., B.A., and S.A. wrote the main manuscript. All authors contributed starting from the inception, data collection, analysis, and interpretation. All authors reviewed the manuscript. The authors read and approved the finalmanuscript.

\section{Authors' information}

Belisa Usmael is MSc graduate in Veterinary Microbiology and working as researcher in Haramaya University owned research projects. Bruk Abraha (DVM) is an Associate Professor in Veterinary Microbiology in College of Veterinary Medicine, Haramaya University, Ethiopia. Sisay Alemu is an Assistant Professor in College of Veterinary Medicine, Haramaya University, Ethiopia. Bahar Mummed is a Lecturer in College of Veterinary Medicine, Haramaya University, Ethiopia. Adem Hiko is a Professor in College of Veterinary Medicine, Haramaya University, Ethiopia. Abdallahi Abdurehman is a Lecturer in College of Veterinary Medicine, Haramaya University, Ethiopia.

\section{Funding}

Not applicable.

\section{Availability of data and materials}

The data used to validate the results of this analysis are available from the first and correspondent authors upon reasonable request.

\section{Declarations}

\section{Ethics approval and consent to participate}

Even thou the study subjects (dogs) are not exposed to damages due to the nature of sample (swab sample), the best practice guidelines for veterinary care were applied during sampling. Because our study didn't include animal experimentation, our study was not subjected to ethical review by "Animal Research Ethical Review Committee of Haramaya University, College of Veterinary Medicine". Rectal swab sample collection was carried out under aseptic conditions without affecting an animal's life. The dog owners were informed and aware about the purpose of the study and verbal informed consent was obtained to conduct the study. In doing so, we don't include any personal data, images, videos, etc. that can violate individual participants.

\section{Consent for publication}

Not applicable.

\section{Competing interests}

The authors declare that they have no competing interests.

Received: 3 August 2021 Accepted: 30 December 2021

Published online: 15 January 2022

\section{References}

1. Quinn P, Markey B, Leonard F, Fitzpatrick E, Fanning S, Hartigan P. Veterinary microbiology and microbial disease. 2nd ed. Syndey: Hometra; 2011.

2. McGavin D, Carlton W, Zachary J. Thompson's special veterinary pathology. Philadephia: Mosby; 2001.

3. Zahraei-Salehi T, Askari-Badouei M, Madadgar O, Ghiasi SR, Ashrafi-Tamai I. Shepherd dogs as a common source for Salmonella enterica serovar reading in Garmsar, Iran. Turk J Vet Anim Sci. 2013;37:102-5. https://doi. org/10.3906/vet-1107-1.

4. OIE (World Organization for Animal Health). Report of the meeting of the OIE ad hoc group on Salmonellosis. May 2010 ed. Paris: World Organisation for Animal Health; 2010.

5. Leonard F. Salmonella infection and carriage: the importance of dogs and their owners. Vet Rec. 2014;174(4):92-3.

6. Kirk MD, Pires SM, Black RE, Caipo M, Crump JA, Devleesschauwer B, et al. World health organization estimates of the global and regional disease burden of 22 foodborne bacterial, Protozoal, and viral diseases, 2010: a data synthesis. PLoS Med. 2015;12(12):e1001921 pmid:26633831.

7. Galanis E, Lo Fo Wong DMA, Patrick ME, Binsztein N, Cieslik A, Chalermchikit T, et al. Web-based surveillance and global Salmonella distribution, 2000-2002. Emerg Infect Dis. 2006;12(3):381-8 https://dx.doi.org/ 10.3201\%2Feid1203.050854. 
8. Ojo O, Adetosoye A. Salmonella Typhimurium infection in diarrhoeic and none-diarrhoeic infection dogs in Ibadan, Nigeria dogs in Ibadan, Nigeria. Veterinarski Arhiv. 2009;79:371-7.

9. Morse E, Duncan M, Estep D, Riggs W, Blackburn B. Canine salmonellosis: a review and report of dog to child transmission of Salmonella Enteritidis. Am J Public Health. 1976;66:82-4.

10. Sato $Y$, Mori T, Koyama T, Nagase H. Salmonella Virchow infection in an infant transmitted by household dogs. J Vet Med Sci. 2000;62(7):767-9. https://doi.org/10.1292/jvms.62.767.

11. Tanaka Y, Katsube $Y$, Imaizumi K. Distribution of salmonellae in the digestive tract and lymph node of carrier-dogs. Japan J Vet Sci. 1976;38:215-24. https://doi.org/10.1292/jvms1939.38.215.

12. Hoelzer K, Moreno-Switt Al, Wiedmann M. Animal contact as a source of human non-typhoidal salmonellosis. Vet Res. 2011;42:34. https://doi. org/10.1186/1297-9716-42-34.

13. Ejo M, Garedew L, Alebachew Z, Worku W. Prevalence and antimicrobial resistance of Salmonella isolated from animal-origin food items in Gondar, Ethiopia. Biomed Res Int. 2016;4290506. https://doi.org/10 1155/2016/4290506.

14. Abdi RD, Mengstie F, Beyi AF, Beyene T, Waktole H, Mammo B, et al. Determination of the sources and antimicrobial resistance patterns of Salmonella isolated from the poultry industry in Southern Ethiopia. BMC Infect Dis. 2017;17(1):352. https://doi.org/10.1186/ s12879-017-2437-2.

15. Kiflu B, Alemayehu H, Abdurahaman M, Negash Y, Eguale T. Salmonella serotypes and their antimicrobial susceptibility in apparently healthy dogs in Addis Ababa Ethiopia. BMC Vet Res. 2017;13:1-9. https://doi. org/10.1186/s12917-017-1055-y.

16. Eguale T, Gebreyes W, Asrat D, Alemayehu H, Gunn JS, Engidawork E. Non-typhoidal Salmonella serotypes, antimicrobial resistance and coinfection with parasites among patients with diarrhea and other gastrointestinal complaints in Addis Ababa, Ethiopia. BMC Infect Dis. 2015;15:497. https://doi.org/10.1186/s12879-015-1235-y.

17. Marami D, Hailu K, Tolera M. Prevalence and antimicrobial susceptibility pattern of Salmonella and Shigella species among asymptomatic food handlers working in Haramaya University cafeterias, Eastern Ethiopia. BMC Res Notes. 2018;11(1):74. https://doi.org/10.1186/ s13104-018-3189-9.

18. WHO. The evolving threat of antimicrobial resistance: options for action. Geneva: World Health Organization; 2012. https://apps.who.int/ iris/handle/10665/44812

19. Feasey NA, Dougan G, Kingsley RA, Heyderman RS, Gordon MA. Invasive non-typhoidal Salmonella disease: an emerging and neglected tropical disease in Africa. Lancet. 2012;379(9835):2489-99 https://dx. doi.org/10.1016\%2FS0140-6736(11)61752-2.

20. Leahy AM, Cummings KJ, Rodriguez-Rivera LD, Rankin SC, Hamer SA. Evaluation of faecal Salmonella shedding among dogs at seven animal shelters across Texas. Zoonoses Public Health. 2016;63(7):515-21. https://doi.org/10.1111/zph.12257.

21. Reimschuessel R, Grabenstein M, Guag J, Nemser SM, Song K, Qiu J, et al. Multilaboratory Survey to Evaluate Salmonella Prevalence in Diarrheic and Nondiarrheic Dogs and Cats in the United States between 2012 and 2014. J Clin Microbiol. 2017:55(5). https://doi.org/10.1128/ JCM.02137-16.

22. Philbey AW, Mather HA, Gibbons JF, Thompson H, Taylor DJ, Coia JE. Serovars, bacteriophage types and antimicrobial sensitivities associated with salmonellosis in dogs in the UK (1954-2012). Vet Rec. 2014;174:94. https:// doi.org/10.1136/vr.101864.

23. Srisanga S, Angkititrakul S, Sringam P, Ho PT, Vo A, Chuanchuen R. Phenotypic and genotypic antimicrobial resistance and virulence genes of Salmonella enterica isolated from pet dogs and cats. J Vet Sci. 2016;18:273-81.

24. Tsai H, Huang H, Lin C, Lien Y, Chou H. Salmonellae and campylobacters in household and stray dogs in northern Taiwan. Vet Res Commun. 2007;31(8):931-9. https://doi.org/10.1007/s11259-007-0009-4.

25. Kocabiyik AL, Cetin C, Dedicova D. Detection of Salmonella spp. in stray dogs in Bursa Province, Turkey: first isolation of Salmonella Corvallis from dogs. J Vet Med B Infect Dis Vet Public Health. 2006;53(4):194-6. https:// doi.org/10.1111/j.1439-0450.2006.00932.x.
26. Bagcigil AF, Ikiz S, Dokuzeylu B, Basaran B, Or E, Ozgur NK. Fecal shedding of Salmonella species in dogs. J Vet Med Sci. 2007;69(7):775-7. https://doi. org/10.1292/jvms.69.775.

27. Seepersadsingh N, Adesiyun A, Seebaransingh R. Prevalence and antimicrobial resistance of Salmonella spp. in non- diarrhoeic dogs in Trinidad. Journal of veterinary medicine. B. Infect Dis Vet Public Health. 2004;51:337-42.

28. Morse E, Duncan M. Canine salmonellosis: prevalence, epizootiology, signs, and public health significance. J Am Vet Med Assoc. 1975;167(9):817-20.

29. Carter M, Quinn J. Salmonella infections in dogs and cats. In: Wray C, Wray A, editors. Salmonella in Domestic Animals. Wallingford: CAB International; 2000. p. 231-44.

30. Philbey AW, Brown FM, Mather HA, Coia JE, Taylor DJ. Salmonellosis in cats in the United Kingdom. 1955 to 2007. Vet Rec. 2009;164(4):120-2. https:// doi.org/10.1136/vr.164.4.120.

31. Viegas FM, Ramos CP, Xavier RGC, Lopes EO, Júnior CAO, Bagno RM, et al. Fecal shedding of Salmonella spp., Clostridium perfringens, and Clostridioides difficile in dogs fed raw meat-based diets in Brazil and their owners' motivation. PLoS One. 2020;15(4):e0231275. https://doi.org/10.1371/ journal.pone.0231275.

32. Finley R, Reid-Smith R, Ribble C, Popa M, Vandermeer M, Aramini J. The occurrence and antimicrobial susceptibility of salmonellae isolated from commercially available canine raw food diets in three Canadian cities. Zoonoses Public Health. 2008;55(8-10):462-9. https://doi.org/10.1111/j. 1863-2378.2008.01147.x.

33. CDC (Centers for Disease Control and Prevention). Update: recall of dry dog and cat food products associated with human Salmonella Schwarzengrund infections-United States, Morbidity and Mortality Weekly Report. 2008; Available at: https://www.cdc.gov/mmwr/preview/mmwrh $\mathrm{tml} / \mathrm{mm} 5744 \mathrm{a} 2 . \mathrm{htm}$

34. Tufa TB, Gurmu F, Beyi AF, Hogeveen H, Beyene TJ, Ayana D, et al. Veterinary medicinal product usage among food animal producers and its health implications in Central Ethiopia. BMC Vet Res. 2018;14:409. https:// doi.org/10.1186/s12917-018-1737-0.

35. Gemeda BA, Amenu K, Magnusson U, Dohoo I, Hallenberg GS, Alemayehu G, et al. Antimicrobial use in extensive smallholder livestock farming Systems in Ethiopia: knowledge, attitudes, and practices of livestock keepers. Front Vet Sci. 2020;7:55. https://doi.org/10.3389/fvets. 2020.00055.

36. Yimer E, Mesfin A, Beyene M, Bekele A, Taye G, Zewdie B, et al. Study on knowledge, attitude and dog ownership patterns related to rabies prevention and control in Addis Ababa, Ethiopia. Ethiop Vet J. 2012;16(2):2739. https://doi.org/10.4314/evj.v16i2.3.

37. Tschopp R, Bekele S, Aseffa A. Dog demography, animal bite management and rabies knowledge-attitude and practices in the Awash Basin, Eastern Ethiopia. PLoS Negl Trop Dis. 2016;10(2):e0004471. https://doi. org/10.1371/journal.pntd.0004471.

38. Sultan A, Eyob H, Olifan Z, Yohannes E. Isolation and Identification of Salmonella from Apparently Healthy Pet Dogs in Holeta Town, Western Shoa, Ethiopia. Curr Trends Biomed Eng Biosci. 2018;15(2):555907. https:// doi.org/10.19080/CTBEB.2018.15.555907.

39. Zewdu E, Miheretu S, Megersa L, Jorga E, Kebebew G, Shiferaw S. Prevalence, risk factors and antimicrobial susceptibility profile of Salmonella isolated from dogs of ambo, Bako and Gojo towns of west Shoa, Ethiopia. Ethiop Vet J. 2019;23:59-77.

40. Sanchez S, Hofarce CL, Lee MD, Maurer JJ, Doyle MP. Animal sources of Salmonellosis in humans. J Am Vet Med Assoc. 2002;221(4):492-7. https:// doi.org/10.2460/javma.2002.221.492.

41. Fukata T, Naito F, Yoshida N, Yamaguchi T, Mizumura Y, Hirai K. Incidence of Salmonella infection in healthy dogs in Gifu prefecture, Japan. J Vet Med Sci. 2002;64(11):1079-80. https://doi.org/10.1292/jvms.64.1079.

42. Leonard EK, Pearl DL, Finley RL, Janecko N, Reid-Smith RJ, Peregrine AS, et al. Comparison of antimicrobial resistance patterns of Salmonella spp. and Escherichia coli recovered from pet dogs from volunteer households in Ontario (2005-06). J Antimicrob Chemother. 2012;67(1):174-81. https:// doi.org/10.1093/jac/dkr430.

43. Polpakdee A, Angkititrakul S, Suksawat F, Sparagano O, Kanistanon K. Epidemiology and antimicrobial resistance of Salmonella sp. isolated from dogs and cats in northeastern Thailand. J Anim Vet Adv. 2012;11(5):61821. https://doi.org/10.3923/javaa.2012.618.621. 
44. Amadi VA, Hariharan H, Arya G, Matthew-Belmar V, Nicholas-Thomas R, Pinckney $R$, et al. Serovars and antimicrobial resistance of non-typhoidal Salmonella isolated from non-diarrhoeic dogs in Grenada, West Indies. Vet Med Sci. 2018;4(1):26-34. https://doi.org/10.1002/vms3.84.

45. Timbs D, Davis G, Carter M, Carman M. The Salmonella excretory incidence of dogs in Hawke's bay. N Z Vet J. 1975;23:54-6.

46. Hackett T, Lappin MR. Prevalence of enteric pathogens in dogs of northCentral Colorado. J Am Anim Hosp Assoc. 2003;39(1):52-6. https://doi. org/10.5326/0390052

47. Procter TD, Pearl DL, Finley RL, Leonard EK, Janecko N, Reid-Smith RJ, et al. A cross-sectional study examining Campylobacter and other zoonotic enteric pathogens in dogs that frequent dog parks in three cities in South-Western Ontario and risk factors for shedding of Campylobacter spp. Zoonoses Public Health. 2014;61(3):208-18. https://doi.org/10.1111/ zph.12062.

48. Lowden P, Wallis C, Gee N, Hilton A. Investigating the prevalence of Salmonella in dogs within the midlands region of the United Kingdom. BMC Vet Res. 2015;11:239. https://doi.org/10.1186/s12917-015-0553-z.

49. Stull JW, Peregrine AS, Sargeant JM, Weese JS. Pet husbandry and infection control practices related to zoonotic disease risks in Ontario, Canada. BMC Public Health. 2013;13:520. https://doi.org/10.1186/ 1471-2458-13-520.

50. Frye JG, Fedorka-Cray PJ. Prevalence, distribution and characterization of ceftiofur resistance in Salmonella enterica isolated from animals in the USA from 1999 to 2003. Int J Antimicrob Agents. 2007;30(2):134-42. https://doi.org/10.1016/j.ijantimicag.2007.03.013.

51. Saleh M, Samson A, Nuhu B, Naphtali N, Adamu S, Shuaibu G, et al. Prevalence of Salmonella infection in dogs in Maiduguri, northeastern Nigeria. Int J Microbiol. 2014;1:5. https://doi.org/10.1155/2014/392548.

52. Finley R, Ribble C, Aramini J, Vandermeer M, Popa M, Litman M, et al. The risk of salmonellae shedding by dogs fed Salmonella-contaminated commercial raw food diets. Can Vet J. 2007;48(1):69-75.

53. Schotte U, Borchers D, Wulff C, Geue L. Salmonella Montevideo outbreak in military kennel dogs caused by contaminated commercial feed, which was only recognized through monitoring. Vet Microbiol. 2007;119(24):316-23. https://doi.org/10.1016/j.vetmic.2006.08.017.

54. PHAC. C-EnterNet 2007 Annual Report: National Integrated Enteric Pathogen Surveillance Program. (2009). (Available at: https://publications.gc.ca/ collections/collection_2010/aspc-phac/HP37-8-2008-eng.pdf).

55. Freeman LM, Chandler ML, Hamper BA, Weeth LP. Current knowledge about the risks and benefits of raw meat-based diets for dogs and cats. JAVMA. 2013:243(11):1549-58.

56. Zewdu E, Cornelius P. Antimicrobial resistance pattern of Salmonella serotypes isolated from food items and personnel in Addis Ababa, Ethiopia. Trop Anim Health Prod. 2009;41(2):241-9.

57. Addis Z, Kebede N, Worku Z, Gezahegn H, Yirsaw A, Kassa T. Prevalence and antimicrobial resistance of Salmonella isolated from lactating cows and in contact humans in dairy farms of Addis Ababa: a crosssectional study. BMC Infect Dis. 2011;11:222. https://doi.org/10.1186/ 1471-2334-11-222.

58. Wabeto W, Abraham Y, Anjulo AA. Detection and identification of antimicrobial-resistant Salmonella in raw beef at Wolaita Sodo municipal abattoir, Southern Ethiopia. J Health Popul Nutr. 2017;36:52 https://dx.doi. org/10.1186\%2Fs41043-017-0131-z.

59. Jajere SM, Onyilokwu SA, Adamu NB, Atsanda NN, Saidu AS, Adamu SG, et al. Prevalence of Salmonella infection in dogs in Maiduguri, Northeastern Nigeria. Int J Microbiol. 2014:392548. https://doi.org/10.1155/2014/ 392548.

60. Tupler T, Levy JK, Sabshin SJ, Tucker SJ, Greiner EC, Leutenegger CM. Enteropathogens identified in dogs entering a Florida animal shelter with normal feces or diarrhea. J Am Vet Med Assoc. 2012;241(3):338-43. https://doi.org/10.2460/javma.241.3.338.

61. Núñez-Castro KM, Muñoz ET, García GF, Herrera-Ramírez JC, Valencia GL, Medina-Basulto GE, et al. Prevalence, risk factors, and identification of Salmonella spp. in stray dogs of northwest Mexico. Austral J Vet Sci. 2019:51(1):37-40. https://doi.org/10.4067/S0719-81322019000100107.

62. Wray C, Wray A. Salmonella in Domestic Animals. Wallingford: CAB International; 2000.

63. Beyene T, Endalamaw D, Tolossa Y, Feyisa A. Evaluation of rational use of veterinary drugs especially antimicrobials and anthelmintics in Bishoftu,
Central Ethiopia. BMC Res Notes. 2015;8:482. https://doi.org/10.1186/ s13104-015-1466-4.

64. Bedada AH, Zewde BM. Tetracycline residue levels in slaughtered beef cattle from three slaughterhouses in Central Ethiopia. Global Veterinaria. 2012;8(6):546-54.

65. Abdulwasi S. An assessment of the effectiveness of the upgrading and revitalization strategies for housing development in case of Harar city. Addis Ababa: MSc Thesis, Ethiopian Civil Service University; 2009.

66. Adimasu DA, Kebede A, Menkir S. Prevalence of antibiotic resistance Salmonella isolates, Entermoeba histolytica and Giardia lomblia in Harar, Eastern Ethiopia. Afr J Microbiol Res. 2014;8(20):2044-53. https://doi.org/ 10.5897/AJMR2014.6714.

67. CSA. Federal Democratic Republic of Ethiopia, central statistical agency. Addis Ababa: Population Projection of Ethiopia for the Year 2014; 2013. p. 4-38.

68. Thrusfield M. Veterinary epidemiology fourth edition. Edinburgh: Veterinary Clinical Sciences Royal (Dick) School of Veterinary Studies, University of Edinburgh; 2018

69. ISO (International Organization for Standardization) 6579:2002/amd 1:2007. Detection of Salmonella species in animal faeces and in environmental samples from the primary production stage, amendment 1, Annex D 2007.

70. ISO (International Organization for Standardization) 6579. Microbiology of food and animal feeding stuff- horizontal method for the detection of Salmonella species. Geneva: International Organization for Standardization; 2002. p. 511-25.

71. CLSI. Performance Standards for Antimicrobial Susceptibility Testing; document M100. 28th ed. Wayne: Second informational supplement, Clinical and Laboratory Standards Institute; 2018.

\section{Publisher's Note}

Springer Nature remains neutral with regard to jurisdictional claims in published maps and institutional affiliations.

Ready to submit your research? Choose BMC and benefit from

- fast, convenient online submission

- thorough peer review by experienced researchers in your field

- rapid publication on acceptance

- support for research data, including large and complex data types

- gold Open Access which fosters wider collaboration and increased citations

- maximum visibility for your research: over 100M website views per year

At BMC, research is always in progress.

Learn more biomedcentral.com/submissions 